\title{
TANTANGAN DALAM DIAGNOSIS DAN MANAJEMEN PADA KEHAMILAN DENGAN THALASSEMIA MAJOR: LAPORAN KASUS
}

\author{
CHALLENGES IN DIAGNOSIS AND MANAGEMENT IN PREGNANCY WITH \\ THALASSEMIA MAJOR: A CASE REPORT
}

\author{
Crismanto Layarta ${ }^{1}$, Arief Prijatna ${ }^{2}$, Ratna Widyastuti ${ }^{2}$ \\ ${ }^{1}$ General Practitioner at Dr. Harjono S. Ponorogo General Hospital, East Java \\ ${ }^{2}$ Obstetrician and Gynaecologist at Dr. Harjono S. Ponorogo General Hospital, East Java \\ Korespondensi: dr. Crismanto Layarta. Email: kurizulayarta@gmail.com
}

\begin{abstract}
ABSTRAK
Talasemia termasuk satu jenis hemoglobinopati, merupakan penyakit genetik yang paling umum di dunia. Kehamilan dengan talasemia mayor berisiko hipoksia janin, pembatasan pertumbuhan intrauterin, prematuritas dua kali kehamilan normal. Kami melaporkan kasus kehamilan pada pasien dengan talasaemia yang diobati dengan buruk, yaitu seorang wanita hamil berusia 28 tahun. Dia datang ke klinik rawat jalan obstetrik untuk perawatan antenatal pertama. Usia kehamilannya adalah 19-20 minggu. Dia didiagnosis dengan talasemia mayor sebelumnya, namun diobati dengan buruk. Dia pucat dan limpanya diperbesar dengan skor Schuffner berjumlah empat. Wajahnya menunjukkan wajah Cooley yang khas ditemukan pada pasien talasemia. Kadar hemoglobin awalnya adalah 2,2 g / dL dengan eritrosit mikrositik hipokromik. Setelah itu, ia menjalani 4 seri transfusi sel darah merah hingga melahirkan. Elektrokardiografi menunjukkan hipertrofi ventrikel kiri dengan iskemia global. Kehamilan dihentikan oleh operasi caesar elektif dengan indikasi disproporsi sefalopelvik. Tidak ada komplikasi intrapartum dan postpartum pada pasien ini. Bayinya 2,800 gram dan panjang $47 \mathrm{~cm}$. Selanjutnya, tidak ada kelainan yang ditemukan pada pemeriksaan neonatal. Kesimpulan untuk presentasi kasus ini adalah menekankan pentingnya pembuatan diagnosis dan pengobatan yang optimal dari talasemia mayor selama kehamilan. Kolaborasi ahli obstetri, ahli jantung, hematologi, dan neonatologis diperlukan untuk mencapai hasil kehamilan yang menguntungkan pada pasien hamil besar thalassemia.
\end{abstract}

Kata Kunci: Thalassemia Mayor, Kehamilan, Hasil

\begin{abstract}
Thalassemia (including one type of haemoglobinopathies) is the most common genetic disease in the world. Pregnancy with thalassemia major is at risks of fetal hypoxia, intrauterine growth restriction, and prematurity as twice as normal pregnancy. We report a case of pregnancy, 28-years-old pregnant woman, in poorly treated thalassemia major patient. She came to obstetric outpatient clinic for the first antenatal care. Her gestational age was 19-20 weeks. She was diagnosed with thalassemia major previously, with poorly treated. She was pale and her spleen was enlarged with Schuffner score amounted to four. Her face showed Cooley facies which is specified in thalassemia patient. Her initial hemoglobin level was $2.2 \mathrm{~g} / \mathrm{dL}$ with hypochromic microcytic erythrocyte. Thereafter, she underwent 4 series of packed red cell transfusion until delivery. The electrocardiography showed left ventricular hypertrophy with global ischemia. The pregnancy was terminated by elective caesarean section by indication of cephalopelvic disproportion. There was no intrapartum and postpartum complication in this patient. Her baby was 2,800 grams and $47 \mathrm{~cm}$ in length. Hereinafter, no abnormalities were found in neonatal examination. This case emphasizes the importance of establishing a diagnosis and the optimal treatment op of thalassemia major during pregnancy. Collaboration of obstetrician, cardiologist, hematologist, and neonatologist is needed to attain favorable pregnancy outcome in thalassemia major pregnant patients.
\end{abstract}

Keywords: Thalassemia Major, Pregnancy, Outcome

How To Cite: Layarta, C., Prijatna, Arief., \& Widyastuti, R. (2019). TANTANGAN DALAM DIAGNOSIS DAN MANAJEMEN PADA KEHAMILAN DENGAN THALASSEMIA MAJOR: LAPORAN KASUS. Biomedia, 11(1), 54-60. doi:https://doi.org/10.23917/biomedika.v11i1.7843

DOI: https://doi.org/10.23917/biomedika.v11i1.7843 


\section{PENDAHULUAN}

Talasemia adalah suatu kelainan pada darah yang diturunkan secara genetik dengan pola autosom resesif. Kelainan ini menyebabkan penurunan produksi hemoglobin fungsional. Hal tersebut menyebabkan penurunan jumlah sel darah merah serta kadar oksigen di dalam tubuh (National Institute of Health (NIH), 2015, US National Library of Medicine, 2018). Talasemia termasuk ke dalam kelompok hemoglobinopati. Hemoglobinopati merupakan salah satu penyakit turunan yang paling sering terjadi (Kyei-Mensah, 2014, Petrikos et al., 2016). Talasemia digolongkan menjadi talasemia alfa dan beta, tergantung dari jenis kromosom yang mengalami kelainan (Perkumpulan Dokter Spesialis Penyakit Dalam Indonesia (PAPDI), 2015). Kejadian talasemia di dunia mencapai 5,2\% dan di Asia Tenggara mencapai 6,6\% (Modell and Darlison, 2008). Prevalensi anemia dalam kehamilan di benua Asia mencapai 39.3\% (Figueiredo et al., 2018).

Data kejadian kehamilan dengan talasemia di Indonesia belum ada. Penelitian yang dilakukan di Rumah Sakit Maharaj Nakorn Chiang Mai, Thailand oleh Wanapirak et al. pada tahun 2004 menunjukkan kejadian talasemia pada kehamilan cukup tinggi yaitu $25,6 \%$ dari $5,6 \%$ ibu hamil yang menderita anemia (Wanapinarak et al., 2004).

Kehamilan yang terjadi pada penderita talasemia dapat beresiko terjadinya hipoksia fetal, pertumbuhan janin terhambat, dan prematuritas dua kali lipat dibandingkan dengan kehamilan normal. Peningkatan risiko transmisi penyakit menular seperti HIV, hepatitis B, dan hepatitis C juga terjadi pada kehamilan dengan talasemia. Kehamilan dengan talasemia yang tidak mendapat terapi tranfusi darah yang inadekuat dapat berisiko pembentukan erhtyrocyte autoantibodies dan hemolytic alloautoantibodies (Capellini et al., 2014, Galanello and Origa, 2010, Zafari and Kosaryan, 2014). Kami melaporkan presentasi klinis dan penatalaksanaan sebuah kasus kehamilan dengan talasemia mayor di rumah sakit kabupaten.

\section{LAPORAN KASUS}

Seorang wanita berusia 28 tahun datang ke Poliklinik Kebidanan RSUD Dr. Harjono S Kabupaten Ponorogo untuk memeriksakan kehamilan pertama kali. Kehamilan ini merupakan kehamilan kedua dengan riwayat abortus sebelummya sebanyak satu kali pada usia kehamilan 5 bulan. Pasien mengeluh pucat dan mudah lelah sejak 1 bulan terakhir dan memberat dalam 7 hari terakhir. Pasien merasa sesak memberat ketika beraktivitas berat serta berjalan lebih dari 300 meter. Hari pertama menstruasi terakhir pasien jatuh pada tanggal 31 Desember 2017 dan saat pemeriksaan awal usia kehamilan sudah mencapai 19-20 minggu. Pasien merupakan penderita talasemia mayor sejak usia 5 tahun dan sudah menjalani transfusi darahsebanyak 2 kali di Surabaya saat berusia 5 tahun dan Solo saat berusia 13 tahun. Pasien tidak rutin kontrol terkait dengan penyakit talasemianya. Tidak ada riwayat keluarga pasien yang menderita penyakit seperti pasien maupun kelainan darah lainnya.

Pada saat kunjungan awal, tinggi badan dan berat badan pasien adalah $145 \mathrm{~cm}$ dan $30 \mathrm{~kg}$. Indeks massa tubuh pasien adalah $14.6 \mathrm{~kg} / \mathrm{m}^{2}$. Lingkar lengan atas pasien terukur $17 \mathrm{~cm}$. Tandatanda vital pasien berada dalam batas normal. Pemeriksaan fisik pada pasien menunjukkan konjungtiva tampak anemis, sklera putih, distensi abdomen akibat kehamilan serta pembesaran organ lien dan terukur Schuffner 4, edema ekstremitas inferior dan akral tampak pucat (Gambar 1).

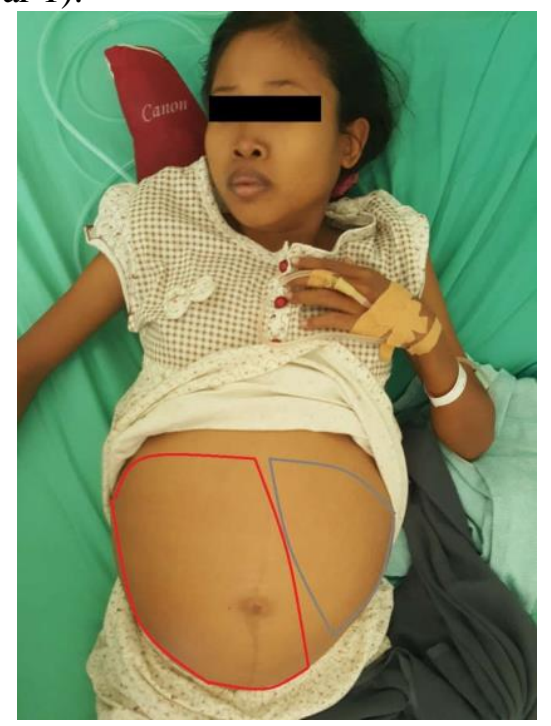

Gambar 1. Foto pasien saat usia kehamilan 28 minggu. Wajah Cooley khas pada pasien talasemia mayor. Tampak proyeksi rahim berdasarkan pemeriksaan fisik (area bergaris merah) dan ukuran lien Schuffner 4 (area bergaris abu-abu)

Pemeriksaan ultrasonografi obstetri yang dilakukan di poliklinik pada saat kunjungan awal menunjukkan hasil janin tunggal hidup intrauterine dengan pengukuran biparietal diameter (BPD) sesuai dengan usia kehamilan 19 minggu, taksiran berat janin 700 gram, denyut jantung janin tampak, serta ditemukan 
splenomegali. Elektrokardiografi menunjukkan adanya hipertofi jantung kiri. Pemeriksaan laboratorium darah lengkap menunjukkan anemia gravis tipe hipokromik mikrositer dengan kadar hemoglobin $2.2 \mathrm{~g} / \mathrm{dL}$, mean cell volume $(\mathrm{MCV})$ $57.2 \mathrm{fl}$, mean cell hemoglobin (MCH) $18.3 \mathrm{pg}$, mean cell hemoglobin $(\mathrm{MCHC}) 32,1 \mathrm{~g} / \mathrm{dL}$, dan trombositopenia dengan jumlah platelet106,000/ $\mu \mathrm{L}$. Pemeriksaan hapusan darah tepi memberikan kesimpulan anemia hipokromik, mikrositik, poikilositosis dan tromobistopenia menggambarkan suspek talasemia dengan diagnosis banding anemia hemolitik dan anemia karena penyakit kronis. Kadar bilirubin total dan bilirubin direk pasien meningkat yaitu 2.08 $\mathrm{mg} / \mathrm{dL}$ dan $0.89 \mathrm{mg} / \mathrm{dL}$. Kadar albumin darah rendah dengan nilai $2.9 \mathrm{~g} / \mathrm{dL}$. Pemeriksaan lainnya yaitu $\mathrm{HBsAg}$ menunjukkan hasil negatif. Pemeriksaan status besi dan elektroforesis $\mathrm{Hb}$ tidak dilakukan karena kendala biaya dan fasilitas laboratorium tidak tersedia.

Berdasarkan keluhan, pemeriksaan fisik, dan penunjang tersebut, diagnosis awal pada pasien adalah GIIP1001 19 minggu, anemia gravis, suspek talasemia mayor, kurang energi kronik, dan hipoalbuminemia. Pasien selanjutnya menjalani rawat inap di ruang perawatan intermediet dengan terapi transfusi packed red cell (PRC) dengan target kadar hemoglobin 10 $\mathrm{g} / \mathrm{dL}$, terapi kelasi besi dengan tablet Ferriprox ${ }^{\circledR}$ (deferiprone) $500 \mathrm{mg} 2 \mathrm{kali}$ sehari, asam folat 1 mg 2 kali sehari, dan terapi simtomatis. Setelah tranfusi darah pertama selesai, pasien diperbolehkan pulang dengan saran untuk melakukan kunjungan antenatal setiap bulan. Pemeriksaan ultrasonografi rutin dikerjakan setiap kunjungan antenatal dan berat badan janin sesuai dengan usia kehamilan. Selama kehamilan berlangsung, pasien menjalani transfusi rutin selama empat kali saat kunjungan antenatal (dalam lima bulan) di rumah sakit dengan kadar hemoglobin setelah transfusi yaitu $8.4 \mathrm{~g} / \mathrm{dL}, 10.5$ $\mathrm{g} / \mathrm{dL}, \quad 8.9 \mathrm{~g} / \mathrm{dL}$, dan $10.5 \mathrm{~g} / \mathrm{dL}$. Kunjungan antenatal dan transfusi darah kedua dilakukan 2 bulan setelah transfusi pertama dengan alasan rumah pasien terlalu jauh dari rumah sakit, namun setelah itu pasien berkunjung ke rumahsakit tiap bulan. Terapi kelasi besi dilanjutkan hingga transfusi terakhir. Pasien sudah tidak mengeluh sesak namun kadang masih merasa mudah lelah dengan aktivitas sedang.

Kunjungan antenatal dilakukan sebanyak empat kali dengan terapi oral berupa tablet asam folat $1 \mathrm{mg} 2$ kali sehari dan tablet kalsium 2,000 mg 1 kali sehari dan dilakukan pemeriksaan darah rutin setiap kali kunjungan dan didapatkan hasil anemia hipokromik mikrositer (rata - rata $6.5 \mathrm{~g} / \mathrm{dL}$ ). Kadar gula darah sewaktu pasien saat usia kehamilan 29-30 minggu adalaj $77 \mathrm{mg} / \mathrm{dL}$. Pemeriksaan laboratorium untuk melihat fungsi kelenjar tiroid yaitu peningkatan free thyroxin (FT4) dan penrunan thyroid stimulating hormone (TSHs) yaitu $9.8 \mu \mathrm{g} / \mathrm{dL}$ (rentang nilai normal 4.65-9.3 $\mu \mathrm{g} / \mathrm{dL}$ ) dan $4.833 \mu \mathrm{IU} / \mathrm{mL}$ (rentang nilai normal 0.27-4.70 $\mu \mathrm{IU} / \mathrm{mL}$ ). Kemudian, pasien dikonsultasikan ke poli penyakit dalam untuk penanganan lebih lanjut dan didiagnosis oleh dokter spesialis penyakit dalam dengan hipertiroid subklinis (dapat terjadi karena kehamilan) dan mendapatkan terapi oral tablet propilthiourasil $50 \mathrm{mg} 2$ kali sehari dan rutin kontrol tiap bulan. Selain itu, pasien juga menjalani konsultasi di poli jantung untuk perencanaan persalinan dengan pemeriksaan elektrokardiografi dengan diagnosis iskemia global karena anemia dan disarankan untuk melakukan persalinan dengan kala II dipercepat.

Saat usia kehamilan mencapai 37 minggu, pasien direncanakan untuk transfusi darah dan persiapan untuk operasi sesar atas indikasi disproporsi sefalopelvik dan talasemia mayor. Pemeriksaan ultrasonografi saat kunjungan antenatal terakhir menunjukkan hasil janin tunggal dan hidup, laki-laki, letak membujur dengan bagian terbawah kepala janin, ukuran tubuh sesuai dengan usia kehamilan 37-38 minggu, amniotic fluid index (AFI) $>8$, jernih, plasenta di korpus lateral kiri grade 2, dan taksiran berat janin 3.100 gram. Kadar hemoglobin sebelum operasi adalah $9.9 \mathrm{~g} / \mathrm{dL}$. Faal koagulasi preoperasi yaitu plasma prothrombin time (PPT) menurun pada nilai 8.2 detik (rentang normal 9.9-11.6 detik) dan activated partial thromboplastin time (aPTT) meningkat pada nilai 37.6 detik (rentang normal 23.9-34.9 detik). Antibiotik profilaksis preoperasi yang diberikan adalah Cefuroxime injeksi 1,5 gram intravena.

Persalinan dilakukan dengan metode operasi seksio sesarea dan melahirkan bayi lakilaki dengan berat badan 2,800 gram dan panjang badan $47 \mathrm{~cm}$. Skor APGAR bayi pada 1 dan 5 menit adalah 8 dan 9. Pemeriksaan fisik pada bayi tidak ditemukan adanya kelainan (Gambar 2). Tidak ada komplikasi saat dan setelah operasi pada pasien, terutama perdarahan pasca persalinan. Setelah operasi, pasien dirawat di ruang perawatan intensif dengan pemeriksaan kadar hemoglobin ulang pasca operasi yaitu 9.2 
g/dL dan Cytotec ${ }^{\circledR} \quad$ (Misoprostol) 600 $\mu \mathrm{g}$ suppositoria dengan observasi kemungkinan perdarahan postpartum dan kardiomiopati postpartum.

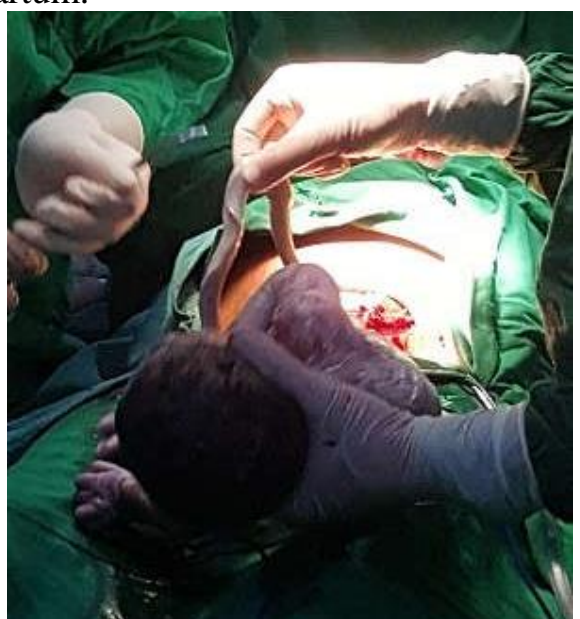

Gambar 2. Proses persalinan bayi dengan operasi seksio sesarea dengan berat badan lahir 2,800 gram

Pasien diminta untuk kontrol tiap minggu selama 2 minggu untuk pemantauan kondisi ibu dan kondisi luka operasi serta diedukasi untuk makan makanan bergizi tinggi protein dan minum obat sesuai anjuran. Terapi oral yang diberikan adalah kapsul Cefadoxil $500 \mathrm{mg} 3$ kali sehari, tablet Meloxicam 7,5 mg 2 kali sehari, dan tablet Hemafort ${ }^{\circledR} 1$ kali sehari diberikan selama 7 hari. Luka operasi menutup dengan baik tanpa ada komplikasi dan tidak ada keluhan pada pasien maupun bayi. Pemeriksaan darah lengkap pasien saat kedua kunjungan masih menunjukkan hasil anemia hipokromik mikrositer dengan kadar hemoglobin $8.8 \mathrm{~g} / \mathrm{dL}$ dan $8.2 \mathrm{~g} / \mathrm{dL}$. Selanjutnya, pasien dirujuk ke poliklinik penyakit dalam untuk tatalaksana talasemia mayor lebih lanjut. Bayi pasien juga menjalani pemeriksaan di poliklinik anak untuk pemeriksaan lebih lanjut dan imunisasi.

\section{PEMBAHASAN}

Kasus ini menggambarkan presentasi klinis pada pasien hamil dengan penyakit talasemia mayor. Beberapa tantangan yang muncul dalam kasus ini adalah penegakan diagnosis, deteksi komplikasi pada ibu maupun janin, dan penatalaksanaan dalam kehamilan maupun persalinan. Diagnosis talasemia, tipe, dan komplikasinya harus ditegakkan dengan bukti pemeriksaan akurat dan standar untuk tatalaksana kasus yang lebih optimal.

Diagnosis anemia dalam kehamilan ditegakkan berdasarkan kadar hemoglobin dalam darah di bawah nilai $11 \mathrm{~g} / \mathrm{Dl}$ (Figueiredo et al.,
2018). Gejala klinis pada pasien talasemia antara lain pucat, icterus, gangguan pertumbuhan, hepatosplenomegali, genu valgum, ulkus di kaki, dan facies Cooley (skull bossing, penonjolan tulang malar, depresi batang hidung, dan hipertrofi maksila). Talasemia sebagai salah satu penyebab terjadinya anemia dalam kehamilan dapat dicurigai pada pemeriksaan $\mathrm{MCH}$ di bawah $25 \mathrm{pg}$. Langkah selanjutnya setelah pemeriksaan kadar MCH dan MCV didapatkan hasil di bawah harga normal adalah pemeriksaan status besi dan elektroforesis hemoglobin (Capellini et al., 2014, Leung and Lao, 2012). Talasemia mayor memiliki gambaran anemia berat dan memerlukan transfusi rutin (Kyei-Mensah, 2014). Berdasarkan riwayat transfusi pasien, gejala klinis, pemeriksaan fisik serta penunjang pada pasien ini, diagnosis talasemia mayor dapat dicurigai pada pasien ini. Namun, untuk menegakkan diagnosis, sebaiknya pemeriksaan lanjutan seperti status besi dan elektroforesis hemoglobin.

Pelayanan antenatal terpadu seharusnya dikerjakan pada kehamilan dengan talasemia setiap bulan hingga usia kehamilan 28 minggu dan selanjutnya tiap 2 minggu. Skrining fungsi jantung, kelenjar tiroid, dan hepar perlu dikerjakan tiap trimester untuk mengetahui perlunya kelasi besi pada kasus iron overload. Skrining diabetes gestasional juga perlu dikerjakan pada usia kehamilan 16 minggu dan diulang lagi pada usia kehamilan 28 minggu (Kyei-Mensah, 2014, Petrikos et al., 2016, Capellini et al., 2014).

Pasien datang pada usia kehamilan 19-20 minggu dengan riwayat talasemia mayor yang tidak mendapatkan transfusi rutin maupun splenektomi (pengobatan tidak adekuat). Pasien tidak melakukan kunjungan secara rutin dan sesuai anjuran dokter dengan alasan rumah pasien jauh. Pemeriksaan fungsi jantung pasien hanya dengan elektrokardiografi pada trimester ketiga dengan hasil bacaan global iskemia. Pemeriksaan fungsi kelenjar tiroid pada trimester ketiga dengan hasil hipertiroid subklinis yang disebabkan oleh kehamilan, tidak ada komplikasi hipotiroid akibat iron overload pada kelenjar tiroid pada pasien ini. Suplementasi asam folat pada kehamilan yang dianjurkan adalah $5 \mathrm{mg}$ karena overaktivitas sumsum tulang dan mencegah terjadinya anemia megaloblastik (Kyei-Mensah, 2014, Daskalakis et al., 1998). Ultrasonografi kehamilan serial dapat digunakan sebagai sarana pemantauan perkembangan janin dalam Rahim (Capellini et al., 2014). 
Transfusi darah pada pasien hamil dengan talasemia mayor perlu dilakukan secara rutin dan optimal untuk menjamin pertumbuhan janin serta menghindari risiko hemolisis dan thrombosis dengan target $10 \mathrm{~g} / \mathrm{dL}$ (Kyei-Mensah, 2014, Petrikos et al., 2016, Capellini et al., 2014, Leung and Lao, 2012). Pasien menjalani transfusi sebanyak 4 kali selama kehamilan namun hanya 2 kali transfusi darah yang berhasil mencapai target. Kondisi ini memerlukan perhatian khusus karena mempengaruhi pertumbuhan janin dalam rahim serta kesehatan ibu. Namun, selama pemeriksaan kehamilan rutin, tidak ada masalah berarti pada ibu maupun janin meskipun terapi transfusi darah belum adekuat.

Pasien sudah pernah menjalani transfusi darah sebanyak dua kali di rumah sakit lain. Transfusi darah, terutama yang dilakukan secara rutin, dapat berisiko terjadi penularan infeksi contohnya hepatitis B, hepatitis C, HIV, human parvovirus B19, dan cytomegalovirus. Risiko ini menjadi dasar untuk dilakukannya pemeriksaan skrining infeksi pada semua wanita (Petrikos et al., 2016). Pada kasus ini, pasien hanya menjalani pemeriksaan hepatitis B yaitu HBsAg dengan hasil negatif. Sebuah penelitian menunjukkan bahwa infeksi hepatitis B jarang terjadi pada pasien dengan talasemia yaitu hanya $4.5 \%$ dari seluruh kehamilan. Infeksi yang sering terjadi pada kehamilan dengan talasemia adalah hepatitis C yaitu 27.3\% (Aessopos et al., 1999).

Terapi kelasi besi pada kehamilan dengan talasemia mayor bersifat kompleks dan individual. Terapi ini seharusnya dikonsultasikan ke ahli hematologi (Kyei-Mensah, 2014). Namun ada penelitian yang menyatakan bahwa medikasi untuk kelasi besi harus dihentikan selama kehamilan. Meskipun demikian, banyak ibu hamil yang tidak memahami hal tersebut dan tidak ada efek berbahaya pada kehamilan yang dilaporkan (Zafari and Kosaryan, 2014).

Desferrioxamine atau defroxamine (DFO) direkomendasikan sebagai terapi kelasi yang aman dalam kehamilan. Sebuah laporan kasus di California tidak menunjukkan komplikasi selama kehamilan dengan terapi kelasi menggunakan deferoxamine (KyeiMensah, 2014, Singer and Vichinsky, 1999). Pemberian DFO sebaiknya dimulai pada trimester kedua (Petrikos et al., 2016). Pasien mendapatkan terapi kelasi Ferriprox ${ }^{\circledR}$ (deferiprone) $500 \mathrm{mg} 2$ kali sehari. Hal ini tidak sesuai dengan rekomendasi maupun panduan internasional, tetapi tidak ditemukan kelainan pada janin selama pemantauan kehamilan.
Deferiprone telah diteliti pada hewan dan dilaporkan kejadian genotoksisitas dan toksisitas pertumbuhan janin, sehingga cenderung mengancam janin (Goldenberg, 2011). Keterbatasan ketersediaan obat di rumah sakit dan hanya terdapat tablet Ferriprox ${ }^{\circledR}$ sebagai terapi kelasi maka tetap diberikan kepada ibu dengan segala risiko, namun tidak ditemukan gangguan pertumbuhan dan kelainan anatomis pada janin.

Talasemia bukan suatu indikasi dilakukannya operasi seksion sesarea pada kehamilan dan manajemen aktif kala III perlu dilaksanakan untuk mencegah perdarahan pasca salin (Kyei-Mensah, 2014). Sebuah penelitian di Thailand menyatakan bahwa sebanyak $32.5 \%$ kehamilan pada pasien yang menderita hemoglobinopati diakhiri dengan metode persalinan operasi sesar (Traisrisilp et al. 2009). Rata-rata persalinan dengan metode operasi seksio sesarea berkisar antara 24\%-10\% (Leung and Lao, 2012). Hampir semua pusat pelayanan (rumah sakit) memilih metode ini sebagai cara persalinan pada pasien dengan talasemia dengan alasan "bayi mahal" (Zafari and Kosaryan, 2014). Seksio sesarea juga dipilih dengan indikasi tingginya kejadian disproporsi sefalopelvik, tinggi badan ibu rendah, osteopenia atau osteoporosis, serta infeksi HIV pada ibu. Metode persalinan yang dipilih pada kasus ini adalah seksio sesarea dengan indikasi disproporsi sefalopelvik dan tinggi badan ibu rendah yaitu $145 \mathrm{~cm}$. Tidak ada komplikasi selama operasi maupun pasca persalinan seperti perdarahan pasca salin, tromboembolisme, dan kardiomiopati postpartum.

Bayi yang dilahirkan oleh pasien dalam kasus ini memiliki berat badan lahir normal yaitu 2,800 gram. Meskipun riwayat terapi tidak optimal maupun penanganan dalam kasus ini belum maksimal, luaran bayi baik dengan skor APGAR 8 pada menit pertama dan 9 pada menit ke-5. Sebuah penelitian yang dilakukan Zafari dan Kosaryan di Iran, 22\% kelahiran bayi memiliki berat badan lahir rendah (Zafari and Kosaryan, 2014).

Tatalaksana postpartum yang perlu dikerjakan pemberian low molecular weight heparin untuk profilaksis mencegah terjadinya tromboembolisme hingga 6 bulan setelah operasi. Pasien juga perlu dikonsultasikan ke ahli jantung untuk pemantauan terjadinya kardiomiopati postpartum. Menyusui sangat disarankan pada ibu kecuali jika ada bukti infeksi hepatitis B, hepatitis C, atau HIV. Terapi kelasi dengan DFO 
juga perlu diberikan selama menyusui (KyeiMensah, 2014, Petrikos et al., 2016). Selama 2 minggu pemantauan setelah operasi, pasien tidak mengutarakan adanya keluhan dan tidak ada komplikasi pada ibu maupun janin.

\section{KESIMPULAN}

Kasus ini menggambarkan kehamilan pada pasien talasemia mayor yang tidak mendapat terapi maupun penegakan diagnosis yang adekuat. Meskipun demikian, tidak terjadi komplikasi fatal pada ibu maupun janin. Luaran kehamilan pada kasus ini baik namun perlu dirujuk ke ahli hematologi anak untuk pemantauan lebih lanjut. Kasu ini menekankan pada pentingnya penegakan diagnosis dan pengobatan optimal pada pasien hamil dengan talasemia mayor. Tatalaksana dalam kasus ini memerlukan kerjasama dari berbagai ahli yaitu ahli kebidanan, ahli jantung, ahli hematologi, dan ahli neonatologi.

\section{DAFTAR PUSTAKA}

Aessopos, A., Karabatsos, F., Farmakis, D., Katsantoni, A., Hatziliami, A., Youssef, J., Karagiorga, M. 1999. Pregnancy in patients with well- treated beta-thalassaemia: outcome for mothers and newborn infants. Am J Obstet Gynecol. 180: 360-365.

Cappellini, M.D., Cohen, A., Porter, J., Taher, A., and Viprakasit, V.2014. Guidelines for the Management of Transfusion Dependent Thalassemia. Cyprus: Thalassemia International Foundation.

Daskalakis, G.J., Papageorgiou, I.S., Antsaklis, A.J., Michalas, S.K. 1998. Pregnancy and homozygous beta thalassemia major. Br J Obstet Gynaecol.105:1028- 1032

Figueiredo, A.C.M.G., Gomes-Filho, I.S., Silva, R.B., Pereira, P.P.S., Mata, F.A.F.D., Lyrio, A.O., Souza, E.S., Cruz, S.S., and Pereira, M.G. 2018. Maternal Anemia and Low Birth Weight: A Systematic Review and Meta-Analysis. Nutrients 2018, 10, 601 pp.1-17

Galanello R \& Origa F, 2010. Beta Thalassemia. Galanello and Origa Orphanet Journal of Rare Diseases 2010, 5:11 pp.1-15

Goldenberg MM, 2011. Pharmaceutical Approval Update. P\&T Vol. 36 No. 12

Kyei-Mensah AAA, 2014. Management of Beta Thalassemia in Pregnancy. Green Top Guideline no. 66. Royal College of Obstetricians and Gynecologists pp.8-11

Leung, T.Y. and Lao, T.T., 2012. Thalassemia in pregnancy. Best Practice \& Research Clinical Obstetrics and Gynaecology 26 (2012) 37-51

Levy, A., Fraser, D., Katz, M., Mazor, M., Sheiner, E. 2005. Maternal anemia during pregnancy is an independent risk factor for low birthweight and preterm delivery. Eur J Obstet Gynecol Reprod Biol. 122:182-186.

Modell, B., and Darlison, M., 2008. Global epidemiology of haemoglobin disorders and derived service indicators. Diakses http://www.who.int/bulletin/volumes/86 /6/06-036673/en/ tanggal 8 April 2018 pukul 13.00

National Institute of Health: National Center for Advancing Translational Sciences, 2015. Thalassemia. Diambil dari: https://rarediseases.info.nih.gov/diseases /7756/thalassemia. Amerika Serikat.

Perkumpulan Dokter Spesialis Penyakit Dalam Indonesia, 2015. Sindrom Talasemia dalam: Penatalaksanaan di Bidang Ilmu Penyakit Dalam: Panduan Klinik Praktis. Jakarta: InternaPublishing, p. 491-493

Petrikos G, Andriopoulos P, Tsironi M. 2016. Pregnancy in women with tahalassemia: challenges and solutions. International Journal of Women's Health 2016:8 441-451 
Singer ST \& Vichinsky EP, 1999. Deferoxamine Treatment during Pregnancy: Is It Harmful?. American Journal of Hematology 60:24-26

Traisrisilp K, Luewan S, Tongsong T. 2009. Pregnancy outcomes inwomen complicated by thalassemia syndrome at Maharaja Nakorn Chiang Mai Hospital. Arch Gynecol Obstet. 279:685-689.

U.S. National Library of Medicine, 2018. Thalassemia. Diambil dari: https://medlineplus.gov/ency/article/000587.htm. Amerika Serikat.

Wanapirak, C., Muninthorn, W., Sanguansermsri, T., Dhananjayanonda, P., Tongsong, T. 2004. Prevalence of thalassemia in pregnant women at Maharaj Nakorn Chiang Mai Hospital. J Med Assoc Thai. Dec;87(12):1415-8

Zafari M \& Kosaryan M, 2014. Marriage and child bearing in patients with transfusion-dependent thalassemia. J. Obstet. Gynaecol. Res. Vol. 40, No. 8: 1978-1982 